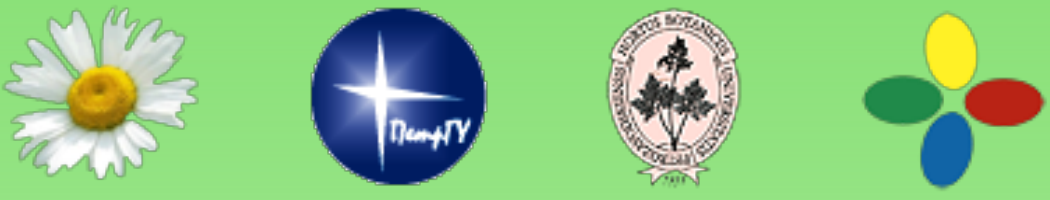

\section{HORTUS BOTANICUS}

Международный электронный журнал ботанических садов

\section{$11 / 2016$}

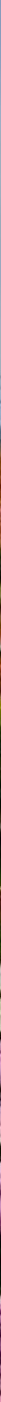


Информационно-аналитический центр Совета ботанических садов России при Ботаническом саде Петрозаводского государственного университета

\section{HORTUS BOTANICUS}

Международный электронный журнал ботанических садов

\section{$11 / 2016$}

ISSN 1994-3849

Эл № ФС 77-33059 от 11.09.2008

Главный редактор
А. А. Прохоров

Редакционный совет

Редакционная коллегия

Редакция

П. Вайс Джексон

Г. С. Антипина

К. А. Васильева

А. С. Демидов

Е. М. Арнаутова

А. В. Еглачева

T. С. Маммадов

А. В. Бобров

С. М. Кузьменкова

В. Н. Решетников

Ю. К. Виноградова

А. Г. Марахтанов

Т. М. Черевченко

Е. В. Голосова

Ю. Н. Карпун

В. Я. Кузеванов

Е. Ф. Марковская

Ю. В. Наумцев

Е. В. Спиридович

А. И. Шмаков

\section{Адрес редакции}

185910, Республика Карелия, г. Петрозаводск, ул. Красноармейская, 31, каб. 12.

E-mail: hortbot@gmail.com

http://hb.karelia.ru

(c) 2001 - 2016 A. A. Прохоров

\section{На обложке:}

На Балу хризантем в Никитском ботаническом саду (фото Ю. Югансона)

\section{Разработка и техническая поддержка}

Отдел объединенной редакции научных журналов ПетрГУ, РЦ НИТ ПетрГу, Ботанический сад ПетрГу 
Сохранение, мобилизация и изучение генетических ресурсов растений

\section{Восточноазиатские элементы флоры в Ботаническом саду Петрозаводского государственного университета}

\section{ПЛАТОНОВА \\ Елена Анатольевна \\ ЛАНТРАТОВА \\ Антонина Степановна \\ ЗАДОРКИНА \\ Екатерина Андреевна}

\section{Ключевые слова:}

наука, еx situ, Ботанический сад, Восточная Азия, интродукция, древесные растения, онтогенез, анатомия побега
Петрозаводский государственный университет, meles@sampo.ru

Петрозаводский государственный университет, mih_val@mail.ru

Петрозаводский государственный университет, garden@psu.karelia.ru

\section{Аннотация:}

Для коллекции древесных растений восточноазиатского происхождения Ботанического сада ПетрГу приводятся результаты оценки разнообразия с учетом таксономического ранга, особенностей ареала, охранного статуса видов, типа жизненной формы, возраста и онтогенетического состояния растений. Полученные положительные результаты многолетней интродукции позволяют более широко рекомендовать 56 исследуемых видов для использования в зеленых насаждениях южной Карелии. Для сеянцев 58 видов древесных растений восточноазиатского происхождения приводится характеристика ранних этапов онтогенетического развития, анализируется анатомия сеянцев Abies holophylla, Picea jezoensis, Picea retroflexa, Pinus densiflora. Получены предварительные данные о высокой жизнеспособности образцов 20 видов восточноазиатского происхождения на ранних этапах развития в условиях Южной Карелии.

\section{Введение}

Первые данные о выращивании инорайонных растений в Карелии относятся ко времени возникновения в средние века новгородских поселений в Обонежье и Поморье. Привезенные паломниками растения из Восточной Азии (Rosa rugosa Thunb., Prunus maackii Rupr. и др.) начали выращиваться в XVI в. на монастырских территориях Валаама и Соловецких островов. Более широкое распространение интродуцированные растения (в том числе и восточноазиатские виды) получили в XX веке, после Великой Отечественной войны, в связи с появлением Сортавальского цветочнодекоративного питомника, питомника в Олонце, Агробиологической станции КарНЦ, Ботанического сада ПетрГу. Также эти виды сохранялись в монастырских и других садах (Лантратова и др., 2003).

Расширение видового разнообразия зеленых насаждений на севере Европы путем введения в культуру новых интродуцированных растений продолжает быть актуальным и в наши дни. Это основополагающий этап разработки принципов создания и сохранения высокофункциональных зеленых насаждений в условиях Севера. Кроме того, коллекции инорайонных растений являются объектами культуры и имеют образовательное значение.

Цель настоящей работы - обобщение результатов интродукции восточноазиатских элементов 
флоры в условиях Карелии, включая анализ ранних этапов интродукции и данные многолетних исследований в Ботаническом саду Петргу.

В задачи исследования входило:

1. Подвести итоги многолетних интродукционных исследований древесных растений восточноазиатской флоры в Ботаническом саду Петргу, выявить виды, перспективные для выращивания в условиях Карелии.

2. Установить особенности начальных этапов развития новых для региона древесных растений восточноазиатской флоры.

\section{Объекты и методы исследований}

Объектами исследований являлись виды региона Восточной Азии, который охватывает Дальний Восток России, Китай, Тайвань, Японию, КНДР, Республику Корея и Монголию. Положение на окраине огромного материка, большая протяженность с севера на юг, наличие высоких горных систем, особенности климата, а также сложность процессов исторического развития обусловили богатство и разнообразие флоры и растительности Восточноазиатского региона, что позволяет рассматривать эту область как богатейший источник для интродукции (Waddington, 1942). Здесь располагается Восточноазиатский интродукционный центр Голарктического царства (Тахтаджян, 1974). Среди провинций этого центра наибольший интерес представляют Маньчжурская, Хоккайдо-Сахалинская и Японо-Корейская. Эта территория в течение длительного времени не подвергалась четвертичному оледенению, имела благоприятные природно-климатические условия, что способствовало формированию богатой флоры сосудистых растений. Она насчитывает более 20 тыс. видов, среди них 14 эндемичных семейств и более 300 эндемичных родов (Тахтаджян, 1978). Многие исследователи подчеркивают широкую экологическую пластичность растений из областей муссонного климата (Кауров, 1955; Лучник, 1970; Нестерович, 1950; Петухова, 1973 и др.).

Основной территорией для проведения исследований является Ботанический сад ПетрГу, который расположен на берегу Петрозаводской губы Онежского озера, на южном склоне Соломенской гряды, сложенной древними вулканогенными породами (Куликов, Куликова, 2001). Территория находится в среднетаежной подзоне, в области умеренно-континентального климата с чертами морского. Зона морозостойкости (USDA zone) 4 (Magarey, 2008).

Посев и выращивание растений проводится в семенном питомнике Ботанического сада в условиях открытого грунта, посев и уход за сеянцами курирует агроном Т. А.Тимохина. Основная коллекция восточноазиатской дендрофлоры располагается в арборетуме Ботанического сада (рис. 1). Арборетум занимает живописную территорию площадью около 12 га с выходами скал, понижениями, небольшим искусственным водоемом, родниками. Почвы маломощные с множеством валунов, преимущественно подзолистые и дерново-подзолистые. Стиль сада пейзажный с элементами регулярных посадок. Принцип размещения растений в экспозициях - географический. При создании экспозиций приоритет отдается групповому размещению древесных растений. Основная часть посадок в Восточноазиатском отделе арборетума производилась в 1951-1965 гг. и курировалась сотрудниками кафедры ботаники биологического факультета ПетрГУ А. С. Лантратовой и Е. Ф. Овчинниковой. Позднее коллекция была дополнена куратором арборетума М. Н. Потаповой, в последние годы - ведущим специалистом БС А. В. Еглачевой.

\section{Методы исследований}

Названия растений в работе приводятся согласно The Plant List (2013). Оценка разнообразия коллекции проводилась с учетом таксономического ранга, особенностей ареала, охранного статуса видов, типа жизненной формы, возраста и онтогенетического состояния растений, зимостойкости. Определение онтогенетического состояния древесных растений проводили согласно периодизации онтогенеза Т. А. Работнова, дополненной для древесных растений (Диагнозы и ключи..., 1979). Зимостойкость и перспективность определяли на основе методики П. И. Лапина, С. В. Сидневой (1973).

Новые образцы растений заказывались из ботанических садов России и некоторых стран Европы. Предпосевная подготовка семян включала стратификацию согласно методическим рекомендациям М. Г. Николаевой (1985). Семена высевали в открытый грунт в конце мая - начале июня. Растения 
выращивали в горшках, с притенением в июне-июле, на зиму укрывали лапником. Определяли продолжительность онтогенетических состояний растений, зимостойкость, для некоторых хвойных растений - анатомическое строение и степень одревеснения по 5-ти балльной шкале (Бессчетнов, Бессчетнова, 2013).

\section{Результаты и обсуждение}

Согласно имеющимся в литературе данным, на территории России и сопредельных стран интродуцировано 743 вида растений Восточноазиатской области, из них 400 видов древесных растений (Воробьев, 1958). В составе зеленых насаждений Карелии насчитывается 99 видов Восточноазиатского исходного центра, что составляет 24.5 \% от общего числа интродуцированных древесных растений республики (Лантратова и др., 2007).

В Ботаническом саду ПетрГу представлена довольно обширная коллекция (73 вида) восточноазиатской дендрофлоры. Большинство видов выращивается в специализированном Восточноазиатском отделе арборетума Ботанического сада. Несколько восточноазиатских видов размещаются в декоративном арборетуме, сирингарии и отделе плодово-ягодных растений.

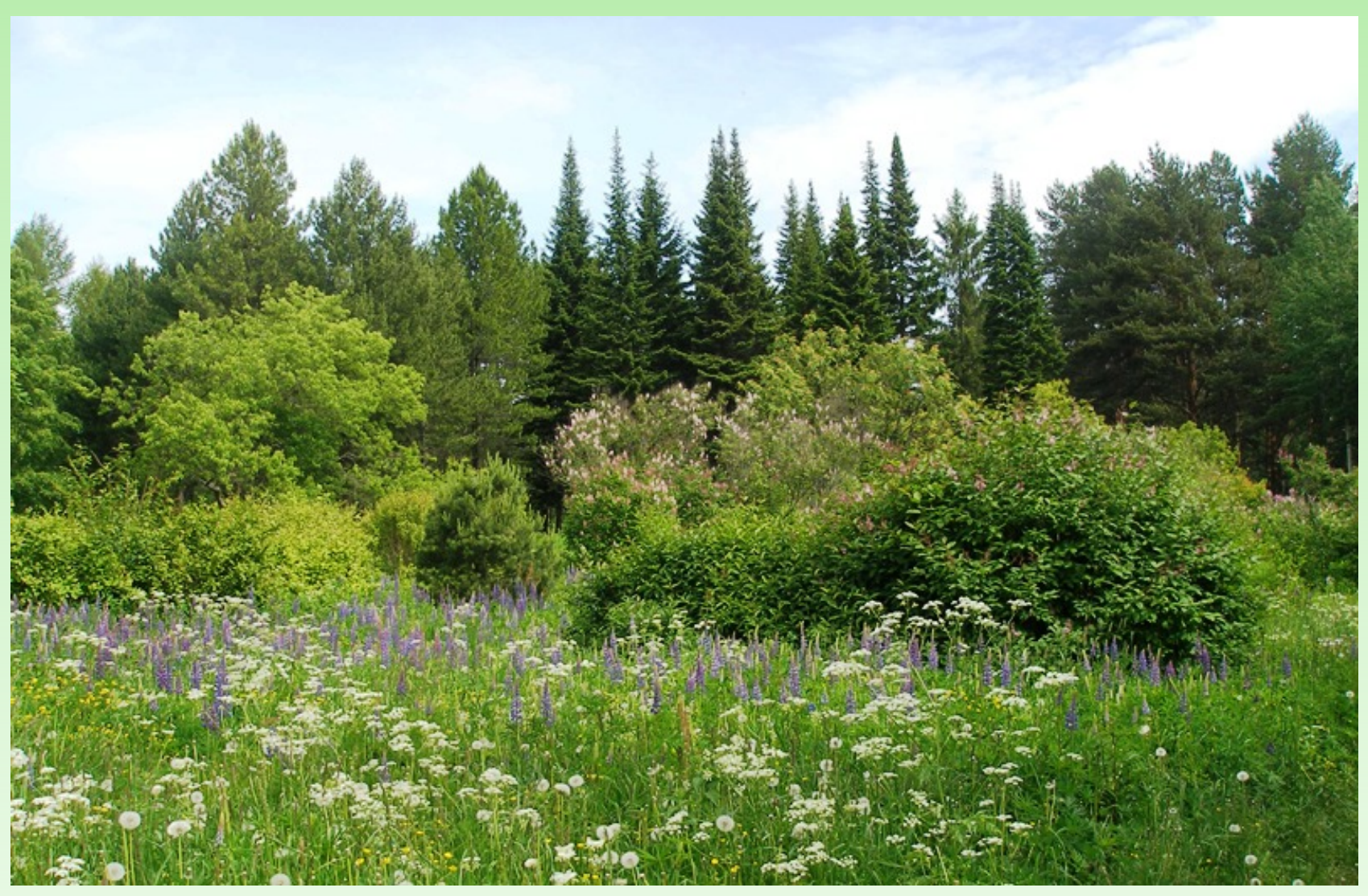

Рис. 1. Восточноазиатский отдел арборетума Ботанического сада Петргу.

Fig. 1. East Asian department of arboretum of Botanic garden of PetrSU.

В составе коллекции преобладают покрытосеменные растения (отдел Magnoliophyta) - 77 \%, хвойные растения (отдел Pinophyta) составляют 22 \%, 1 вид (1\%) принадлежит отделу гинкговидные (Ginkgophyta). Виды относятся к 3 классам, 19 порядкам, 20 семействам, 43 родам. Наибольшее число видов насчитывается в семействах Rosaceae Juss., Pinaceae Lindl., Oleaceae Hoffmanns. \& Link; родах Crataegus L., Spiraea L., Syringa L.

В течение всего периода интродукции в культуру привлекались виды умеренной зоны Дальнего Востока, преимущественно из холодноумеренной подзоны, охватывающей Маньчжурскую и СахалиноХоккайдскую провинции, где доминируют хвойно-широколиственные леса. Ареалы некоторых видов располагаются в южноумеренной подзоне. 
Ареал всех видов полностью или частично лежит в пределах Восточноазиатского региона. Ряд видов имеют более широкий ареал: 11 видов распространены также в Сибири, 2 вида - в Сибири и Средней Азии, ареал 2 видов заходит в Южную Азию, 4 вида имеют евроазиатский ареал, 1 вид распространен также в Северной Америке. Ареал 72 \% видов располагается полностью или частично в России, 28 \% видов имеют ареал, полностью расположенный за пределами страны.

По жизненной форме 31 \% видов представляют собой деревья первой или второй величины на родине, 18 \% - деревья третьей величины, произрастают в подлеске и имеют форму невысокого (около 5-7 м) одно- или многоствольного дерева или кустарника, 47 \% видов - типичные кустарники, 3 вида лианы.

Отдельно отметим редкие виды этого региона, имеющиеся в коллекциях Ботанического сада.

Так, в Красную книгу России (2008) занесены виды Microbiota decussata Kom., Taxus cuspidata Siebold \& Zucc. В Красную книгу Амурской области (2009) внесены Philadelphus tenuifolius Rupr. \& Maxim., Juglans mandshurica Maxim., Pyrus ussuriensis Maxim. ex Rupr., Schisandra chinensis (Turcz.) Baill., Vitis amurensis Rupr., Pinus koraiensis Siebold \& Zucc., Pinus sibirica L. Taxus cuspidata внесен в Красные книги Приморского края (2008), Хабаровского края (2008), Сахалинской области (2005), Pinus sibirica - в Красную книгу Хабаровского края.

Виды Thujopsis dolabrata (L. f.) Siebold \& Zucc. и Chamaecyparis pisifera (Siebold \& Zucc.) Endl. являются эндемиками Японии. По данным Международного союза охраны природы (IUCN) под угрозой исчезновения находятся Ginkgo biloba L., Abies koreana E. H. Wilson (категория исчезающие Еn) (Китай), в состоянии, близком к угрожающему (NT) - Abies holophylla Maxim. (Китай).

54 вида (58 таксонов с учетом подвидов) исследуемых древесных растений произрастают в арборетуме Ботанического сада с 1951-1973 гг., т.е. их возраст насчитывает более 40 лет. Все растения вполне зимостойки; обмерзание однолетних побегов наблюдается у некоторых видов лишь в суровые зимы. Растения этой группы сохраняют присущую им на родине форму роста, обладают высокой побегообразовательной способностью, дают ежегодный прирост побегов. Исследуемые растения достигли генеративного состояния, многие из них дают полноценные семена. Крупные деревья (например, Abies sibirica, Betula ermanii, Betula platyphylla, Juglans mandshurica, Larix gmelinii, L. kaempferi, L. sibirica, Picea obovata, Pinus sibirica, Quercus mongolica, Tilia amurensis и некоторые другие), многие деревья и кустарники подлеска (Acer tataricum ssp. ginnala, Amelanchier asiatica, Sorbus discolor, Syringa reticulata ssp. amurensis, Malus baccata, Rosa davurica, Rosa rugosa и другие) находятся в наиболее продуктивном генеративном состоянии (g2). Боярышники возрастом около 50 лет (Crataegus altaica, C. chlorosarca, C. maximowiczii) завершают свой жизненный цикл и требуют возобновления в коллекции. Еще 2 вида - Actinidia kolomikta, Pyrus ussuriensis - успешно выращиваются в плодово-ягодном отделе и также находятся в генеративном состоянии.

Таким образом, указанные виды Восточноазиатского отдела арборетума, прошедшие многолетнюю интродукцию, являются перспективными в условиях Карелии и могут рекомендоваться для посадки в зеленых насаждениях урбанизированных территорий (табл. 1).

В Восточноазиатском отделе, в составе экспозиции «Декоративный арборетум» и питомнике крупномеров сада имеются и более молодые группы древесных растений. Недавно вступили в генеративное состояние Abies koreana, Microbiota decussata, Thujopsis dolabrata, Abies holophylla, Berberis thunbergii (Еглачева и др., 2014). В имматурном состоянии находятся Pinus koraiensis, Caragana pygmaea (L.) DC., в виргинильном - Chamaecyparis pisifera, Juniperus chinensis L., Juniperus squamata Buch. Ham. ex D. Don, Taxus cuspidata (Еглачева и др., 2014), Euonymus fortunei (Turcz.) Hand. - Mazz., Abies nephrolepis (Trautv. ex Maxim.) Maxim., Phellodendron amurense Rupr., Schisandra chinensis, Stephanandra incisa (Thunb.) Zabel, Vítis amurénsis и другие. Эти виды растений хорошо зарекомендовали себя на ранних этапах интродукции, но их исследования в условиях Карелии нельзя назвать завершенными. Опыт выращивания Ginkgo biloba показал неустойчивость этого вида, в более суровые зимы он вымерзает.

В настоящее время идет интенсивная работа по дальнейшему обогащению дендрологической коллекции восточноазиатской флоры. В 2013-2014 гг. семенной питомник Ботанического сада 
пополнился 95 образцами 58 видов (60 таксонов с учетом подвидов) древесных растений, принадлежащих 32 родам, 15 семействам, 10 порядкам, 2 отделам. Семена были получены из 39 Ботанических садов России и европейских стран. Растения заказывали с целью обогащения родовых комплексов: Abies Mill., Picea A. Dietr., Pinus L., Juniperus L., Acer L., Betula L., Crataegus L., Euonymus L., Lonicera L., Rosa L., Sorbus L., Quercus L. Tакже внимание уделялось некоторым декоративным представителям других родов. Для проведения интродукционных исследований были выбраны виды, способные произрастать в 3 и 4 зонах морозостойкости. Большинство видов привлекаются в интродукцию в Карелии впервые, некоторые выращивались в Ботаническом саду Петргу ранее, но по различным причинам выпали из коллекций; отдельные виды выращиваются для пополнения уже существующих единичных посадок и создания групп.

Большая часть (65 \%) видов имеют естественный ареал в России, остальные - за пределами страны. Ареал 45 исследуемых видов лежит в пределах Восточноазиатского региона, ареал 13 видов включает также районы Сибири, одного - Среднюю Азию, двух - Центральную Азию. Среди исследуемых образцов встречаются редкие и исчезающие виды растений. В Красную книгу России (2008) включены: Picea glehnii, Pinus densiflora, Juniperus chinensis var. sargentii, Prinsepia sinensis. В Красную книгу Амурской области (2009) дополнительно к видам всероссийского значения внесены Maackia amurensis, Phellodendron amurense, в Красную книгу острова Сахалин (2005) - Prunus sachalinensis. По данным Международного союза охраны природы (IUCN) под угрозой исчезновения находятся эндемики Китая Picea retroflexa (категория En) и Picea asperata (категория уязвимые Vul).

Развитие исследуемых образцов происходило неравномерно (табл. 2, рис. 2, 3). Всходы появлялись в первый вегетационный сезон у большинства образцов хвойных растений, представителей родов Berberis L., Lonicera L., Philadelphus L., также у Betula davurica, Betula utilis, Corylus heterophylla и других (табл. 2). На второй год наблюдалось появление всходов у образцов Acer barbinerve, Acer pseudosieboldianum, Chaenomeles speciosa, Cotoneaster horizontalis, Malus sieboldii, Phellodendron amurense, Prunus sachalinensis и других. В течение первого и второго года появлялись всходы Crataegus chlorosarca, Lespedeca bicolor, Maackia amurensis, Rosa multiflora, Sibiraea laevigata, Sorbus tianschanica, Weigela praecox.

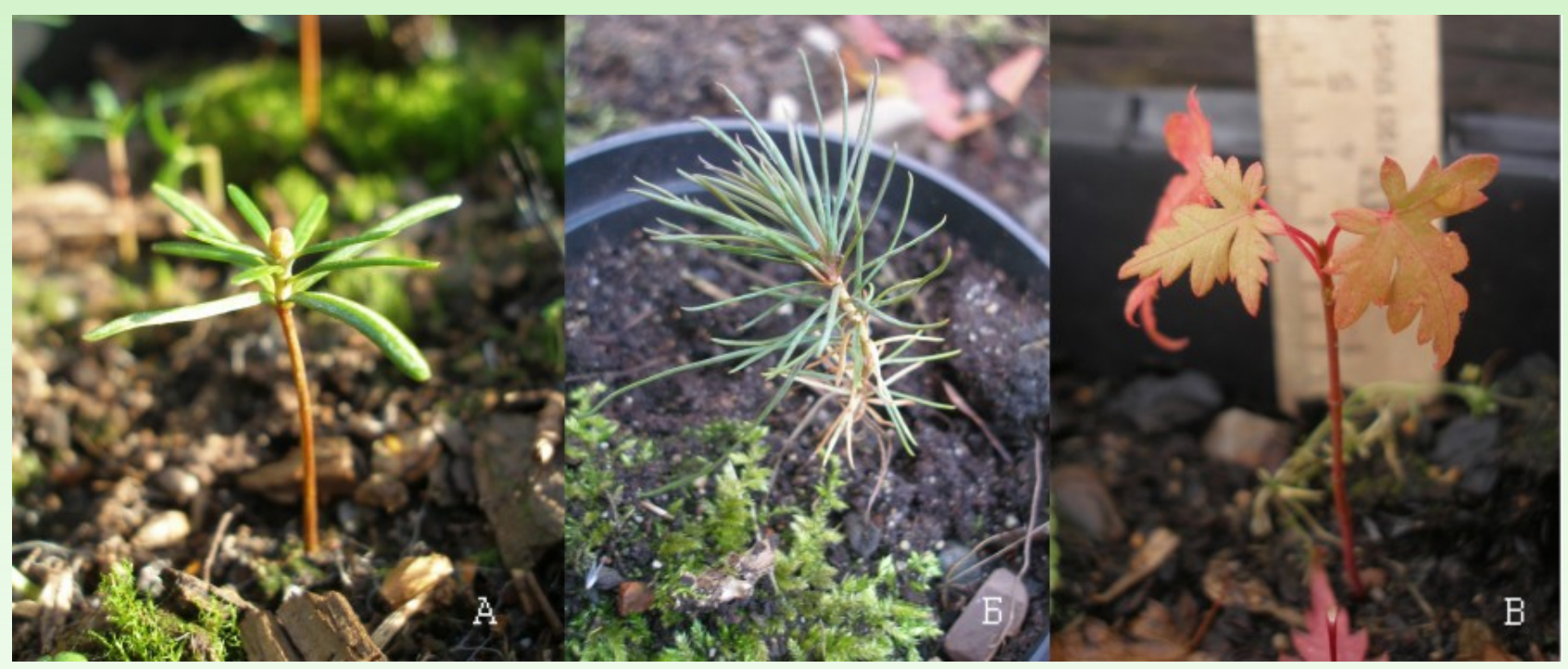

Рис. 2. Ювенильные растения: А) Abies sachalinensis (1 год), Б) Pinus densiflora (2 года), В) Acer barbinerve (1 год).

Fig. 2. Juvenile plants: A) Abies sachalinensis (1 year old), 5) Pinus densiflora (2 years old), B) Acer barbinerve (1 year old). 


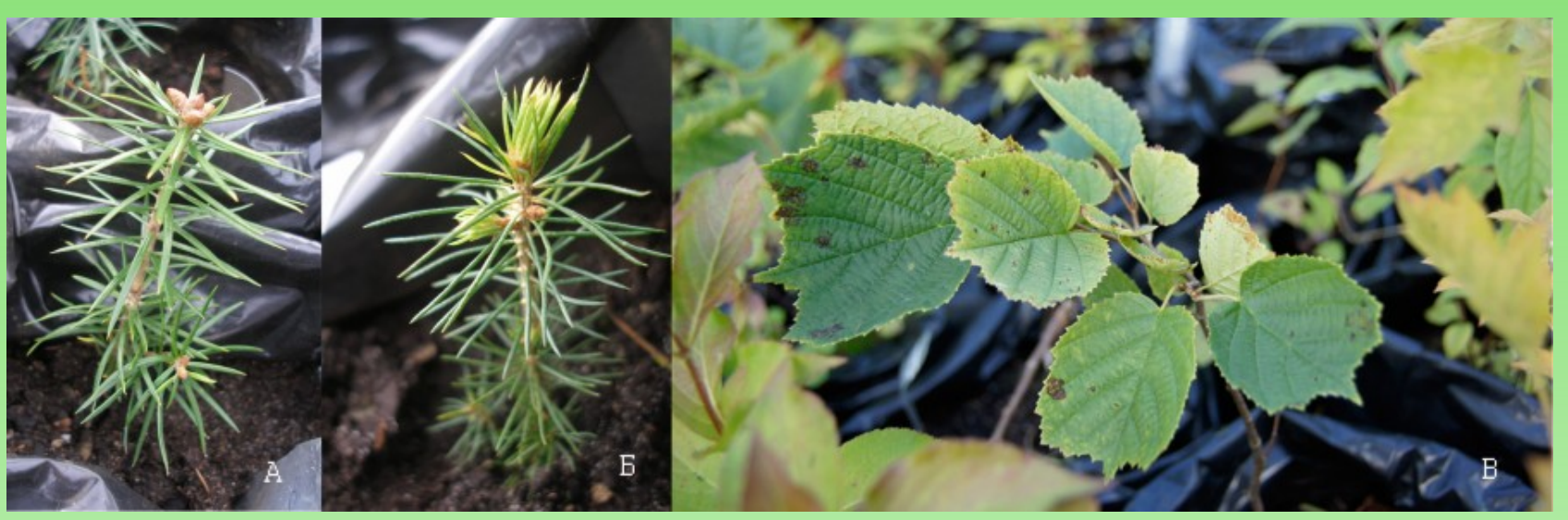

Рис. 3. Имматурные растения: A) Abies holophylla (3 года), Б) Picea asperata (3 года), В) Corylus heterophylla (4 года).

Fig. 3. Immature plants: A) Abies holophylla (3 years old), 5) Picea asperata (3 years old), B) Corylus heterophylla (4 years old).

Дальнейшее онтогенетическое развитие сеянцев различных видов также происходило неравномерно. Большинство исследуемых хвойных растений родов Abies Mill., Juniperus L., Larix Mill., Picea A. Dietr. уже на второй год переходили в имматурное состояние. Развитие образцов рода Ріnиs L., видов Abies holophylla и Picea jezoensis происходило в более растянутые сроки. Среди покрытосеменных наиболее быстрыми темпами развивались сеянцы Betula utilis, Berberis thunbergii, Cotoneaster horizontalis, Rosa multiflora. В течение первого вегетационного сезона они проходили состояние проростков, ювенильное и вступали в имматурное состояние. Уже на второй год у отдельных растений Rosa multiflora наблюдалось цветение.

Большинство исследуемых покрытосеменных растений переходили в имматурное состояние $\mathrm{k}$ концу второго вегетационного сезона, например, Corylus heterophylla, Lespedeca bicolor, Lonicera gibbiflora и другие. Для ряда образцов продолжительность ювенильного состояния была более длительной (1-2 года), развитие разных образцов шло неравномерно, например, Crataegus chlorosarca, Crataegus pinnatifida, Crataegus dahurica, Euonymus alatus, Euonymus maackii, Euonymus macropterus, Rhamnus erythroxylon, Sorbus tianschanica, Weigela praecox. И лишь на 3-4 год вступали в имматурное состояние сеянцы Acer pseudosieboldianum, Berberis koreana, Chaenomeles speciosa, Euonymus hamiltonianus, Maackia amurensis, Phellodendron amurense. Ювенильное состояние продолжалось у них 2-3 года.

По зимостойкости растений получены следующие результаты (табл. 3). Последние три зимних периода существенно отличались по погодным условиям: от сравнительно теплых малоснежных зим 2013-2014 гг. и 2014-2015 гг. до многоснежной зимы 2015-2016 года с морозами до -30 С. Благополучно перенесли зимний период в ювенильном состоянии Abies nephrolepis, Abies veitchii, Juniperus chinensis var. sargentii, Pinus koraiensis, Acer barbinerve, Acer pseudosieboldianum, Crataegus maximowiczii, Malus sieboldii, Phellodendron amurense, Tilia mongolica; в ювенильном и имматурном состояниях - Picea glehnii, Picea retroflexa, Pinus densiflora, Berberis koreana, Berberis thumbergii, Betula davurica, Betula utilis, Caragana microphylla, Corylus heterophylla, Crataegus pinnatifida, Lonicera chrysantha, Prunus sachalinensis, Rhamnus erythroxylon, Sibiraea laevigata, Sorbus koehneana, Sorbus tianschanica.

В течение зимнего периода погибали отдельные растения образцов Larix gmelinii var. olgensis, Larix gmelinii, Abies sachalinensis, Quercus mongolica subsp. crispula, Weigela subsessilis, Rhodotypos scandens и др. У ряда видов (Abies sachalinensis, Picea jezoensis, Picea asperata, Caragana boissii, Crataegus chlorosarca, Prinsepia sinensis, Weigela praecox, некоторых образцов рода Euonymus) это было обусловлено более поздним развитием отдельных сообей в первый год жизни. Зимой 2015-2016 гг. наблюдалась гибель образцов Euonymus alatus, Weigela praecox, Weigela subsessilis.

Происходило частичное зимнее обмерзание побегов Rhodotypos scandens, Prinsepia sinensis, Philadelphus subcanus var. magdalenae, Menyspermum davuricum, Lonicera gibbiflora, Lonicera ferdinandii, 
Lespedeca bicolor, Exochorda racemosa. Возможно, у некоторых видов (Rhodotypos scandens, Prinsepia sinensis, Lespedeca bicolor, Menyspermum davuricum) это объясняется незавершенностью лигнификации годичных побегов.

В целом успешность ранних этапов интродукции мы можем оценить для тех образцов, которые представлены достаточным количеством особей (более 5), имеют нормальное онтогенетическое развитие, отличаются относительно высокой зимостойкостью: Abies holophylla, Abies sachalinensis, Larix gmelinii, Picea asperata, Picea glehnii, Picea jezoensis, Picea retroflexa, Pinus densiflora, Acer pseudosieboldianum, Berberis thunbergii, Chaenomeles speciosa, Cotoneaster horizontalis, Crataegus chlorosarca, Crataegus dahurica, Crataegus pinnatifida, Euonymus macropterus, Phellodendron amurense, Rhamnus erythroxylon, Sibiraea laevigata, Sorbus sambucifolia.

Исследование анатомии сеянцев позволяет отследить процессы формирования анатомических структур в ходе развития, выявить возможные причины выпада растений, особенно на ранних этапах онтогенеза и прогнозировать успех интродукции. Такие исследования были проведены для сеянцев видов хвойных.

В конце первого вегетационного сезона сеянцы Abies holophylla, Picea jezoensis, Picea retroflexa, Pinus densiflora находятся в ювенильном состоянии. Побеги имеют элементы первичной и вторичной структуры (рис. 4, 5, 6). Присутствует эпидерма, феллоген и феллодерма (происходит образование многослойной эпидермы - коры), хорошо развита паренхима первичной коры. Из элементов вторичной структуры наиболее развита ксилема. На срезах Pinus densiflora концу первого вегетационного сезона хорошо заметны зачатки смоловыделительных каналов. Из них хорошо сформированы 4, слабо развиты - 3 канала (рис. 7). На второй год развития растения Pinus densiflora продолжают оставаться в ювенильном состоянии, но структура побегов изменяется. Хорошо развита многослойная эпидерма, паренхима первичной коры занимает меньшую часть среза по сравнению с первым годом развития. Происходит увеличение объема вторичной ксилемы, к концу сезона хорошо сформированы 6, присутствуют 3 зачатка смоловыделительных каналов (рис. 8). По интенсивности окрашивания срезов можно судить о высокой степени лигнификации проводящих тканей к концу вегетационного сезона, таким образом, обеспечивается подготовка к зимовке исследуемых растений. В целом анатомическая структура побегов исследуемых хвойных растений не отклоняется от нормы, что свидетельствует об успешности их интродукции в условиях Карелии.

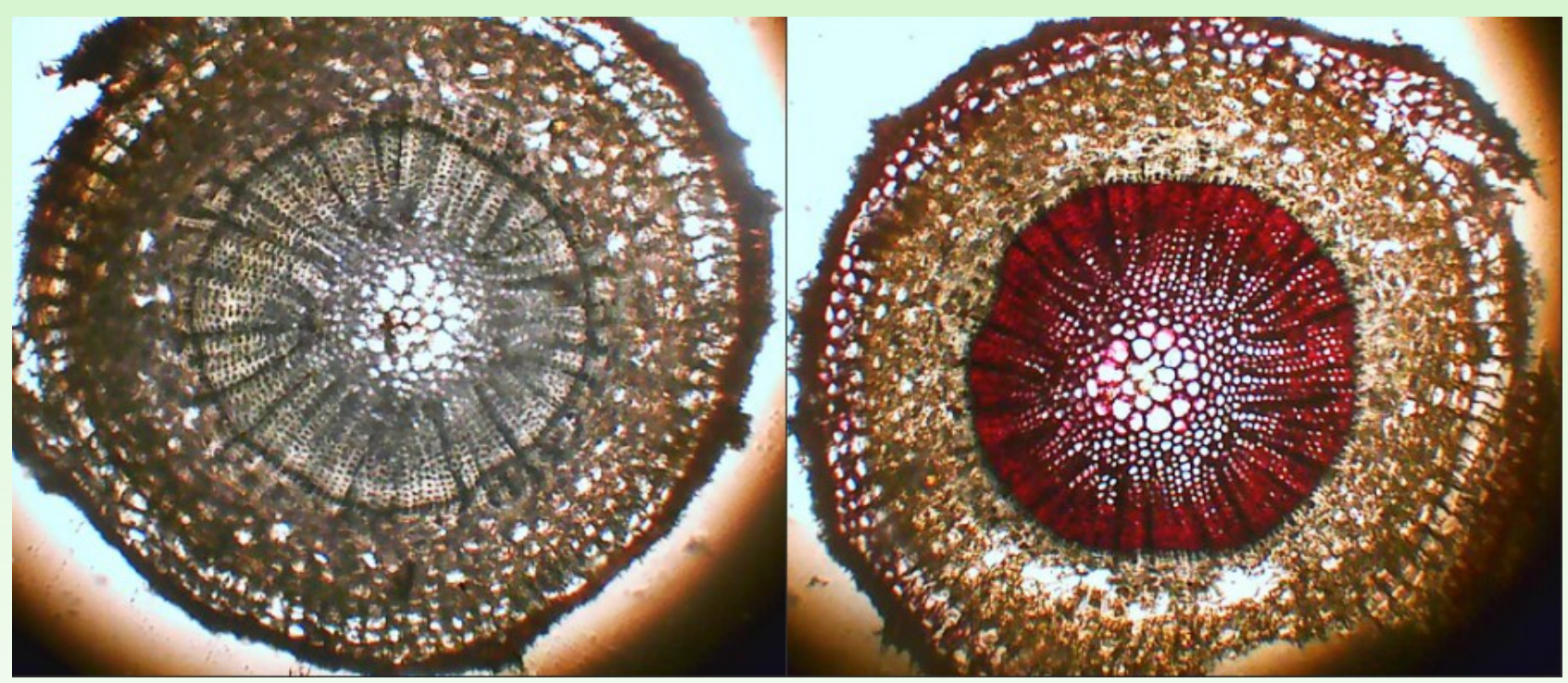

Рис. 4. Поперечный срез однолетнего побега Abies holophylla. Увеличение 1:10.

Fig. 4. Microscopic cross-section of 1-year Abies holophylla stem. Magnification 1:10. 


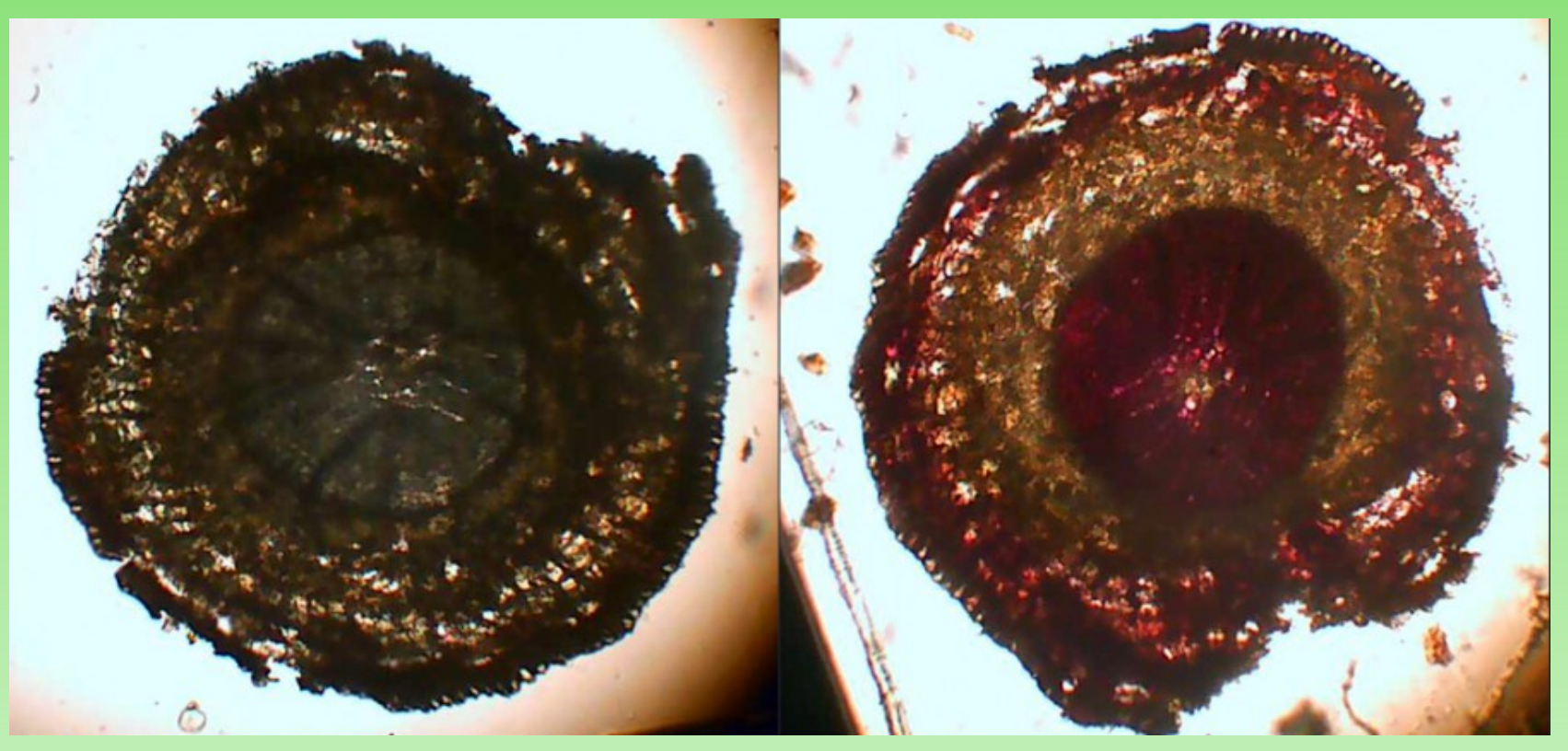

Рис. 5. Поперечный срез однолетнего побега Picea jezoensis. Увеличение 1:10.

Fig. 5. Microscopic cross-section of 1-year Picea jezoensis stem. Magnification 1:10.

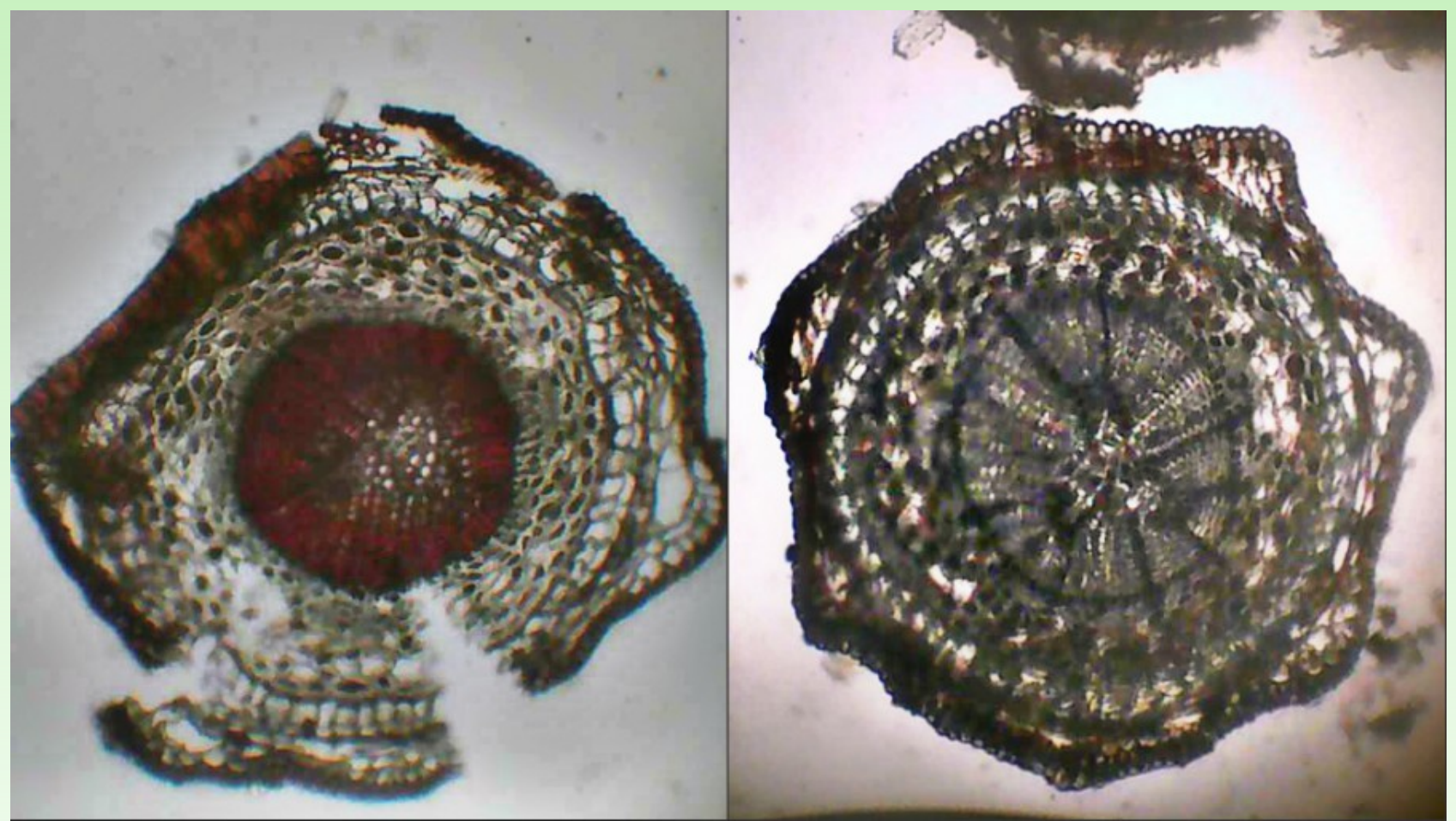

Рис. 6. Поперечный срез однолетнего побега Picea retroflexa. Увеличение 1:10.

Fig. 6. Microscopic cross-section of 1-year Picea retroflexa stem. Magnification 1:10. 


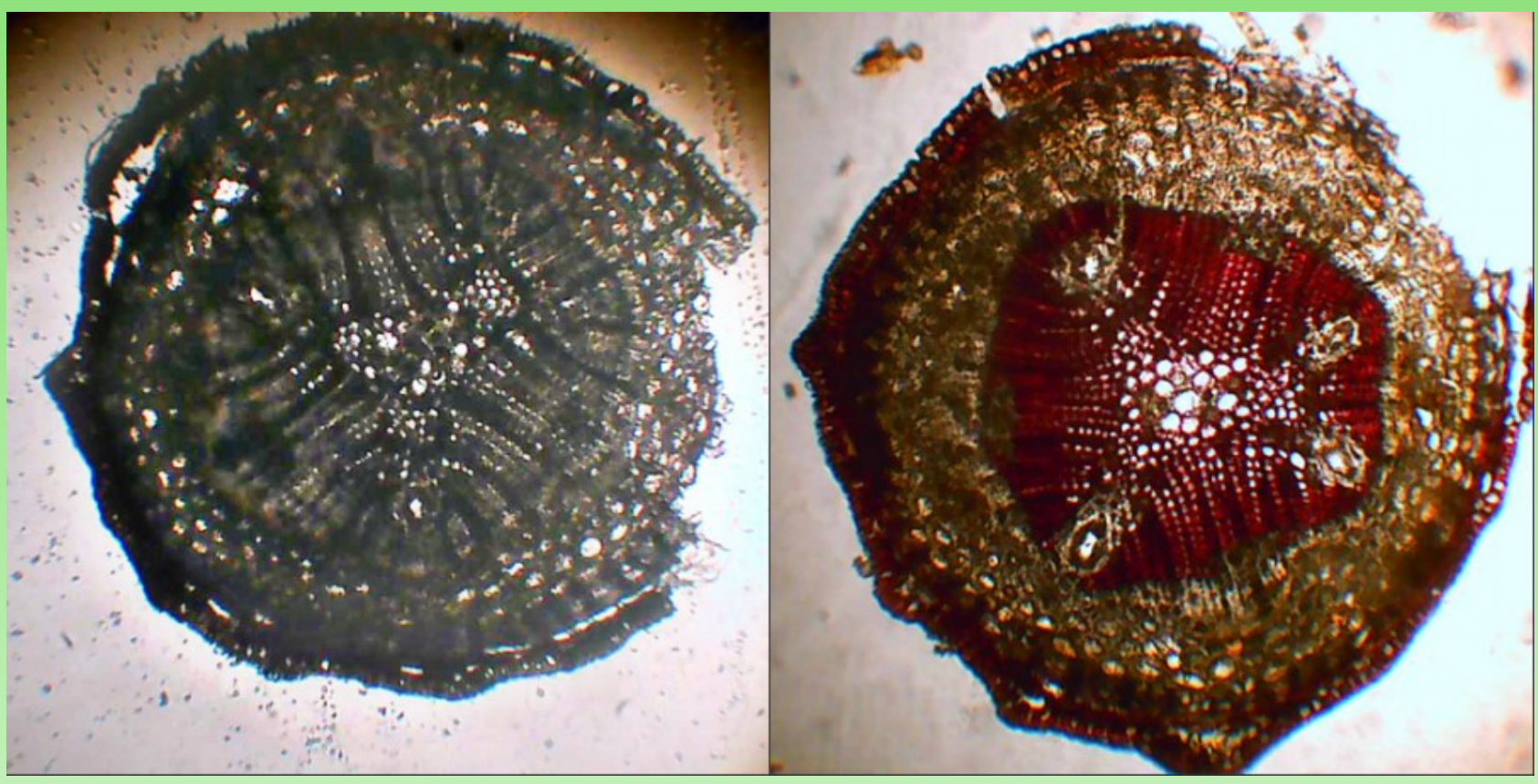

Рис. 7. Поперечный срез однолетнего побега Pinus densiflora. Увеличение 1:10.

Fig. 7. Microscopic cross-section of 1-year Pinus densiflora stem. Magnification 1:10.

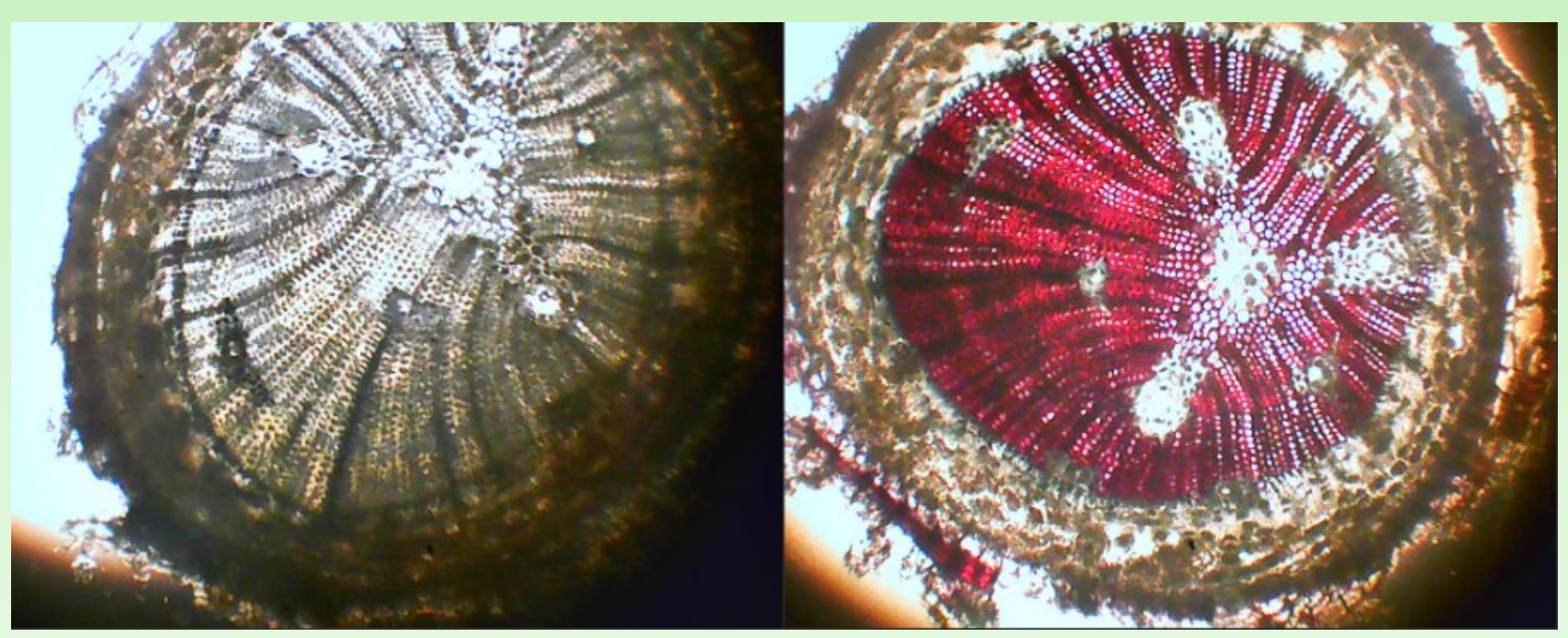

Рис. 8. Поперечный срез 2-летнего побега Pinus densiflora. Увеличение 1:10.

Fig. 8. Microscopic cross-section of 2-year Pinus densiflora stem. Magnification 1:10.

Таблица 1. Перспективные виды (и подвиды) древесных растений восточноазиатского происхождения, выявленные в результате многолетних исследований в Ботаническом саду ПетрГу

Table 1. Prospective species (and subspecies) of East Asian woody plants according to the results of longterm growing and investigations in the Botanical Garden of PetrSU

1. Abies sibirica Ledeb.

2. Acer tataricum subsp. ginnala (Maxim.) Wesm. (= Acer ginnala Maxim.)

3. Actinidia kolomikta (Rupr. \& Maxim.) Maxim.

4. Amelanchier asiatica (Siebold \& Zucc.) Endl. ex Walp.

5. Berberis amurensis Rupr.

6. Betula ermanii Cham.

7. Alnus japonica (Thunb.) Steud. (= Betula japonica Thunb.)

8. Betula grossa Siebold \& Zucc. (= Betula ulmifolia Siebold \& Zucc.) 
9. Betula platyphylla Sukaczev

10. Betula platyphylla subsp. mandshurica (Regel) Kitag. (= Betula mandshurica (Regel) Nakai)

11. Chaenomeles japonica (Thunb.) Lindl. ex Spach

12. Corylus sieboldiana var. mandshurica (Maxim.) C. K. Schneid. (= Corylus mandshurica Maxim.)

13. Crataegus altaica Ledeb.

14. Crataegus chlorosarca Maxim.

15. Crataegus maximowiczii C. K. Schneid.

16. Crataegus sanguinea Pall.

17. Forsythia ovata Nakai

18. Hydrangea bretschneideri Dippel

19. Hydrangea xanthoneura Diels

20. Juglans mandshurica Maxim.

21. Larix gmelinii (Rupr.) Kuzen.

22. Larix kaempferi (Lamb.) Carrière

23. Larix sibirica Ledeb.

24. Lonicera chrysantha Turcz. ex Ledeb.

25. Malus baccata (L.) Borkh.

26. Philadelphus incanus Koehne

27. Philadelphus schrenkii Rupr.

28. Philadelphus subcanus var. magdalenae (Koehne) S. Y. Hu (= Philadelphus magdalenae Koehne)

29. Philadelphus tenuifolius Rupr.

30. Physocarpus amurensis (Maxim.) Maxim.

31. Picea obovata Ledeb.

32. Pinus pumila (Pall.) Regel

33. Pinus sibirica Du Tour

34. Prunus maackii Rupr.

35. Prunus padus L. (= Padus asiatica Kom.)

36. Pyrus ussuriensis Maxim. ex Rupr.

37. Quercus mongolica Fisch. ex Ledeb.

38. Rosa davurica Pall.

39. Rosa rugosa Thunb.

40. Salix schwerinii E. L. Wolf

41. Sorbaria sorbifolia (L.) A. Braun

42. Sorbus discolor (Maxim.) Maxim.

43. Sorbus aucuparia subsp. sibirica (Hedl.) Krylov (= Sorbus sibirica Hedl.)

44. Spiraea betulifolia Pall.

45. Spiraea canescens D. Don

46. Spiraea chamaedryfolia L.

47. Spiraea japonica L. f.

48. Spiraea media Schmidt

49. Spiraea salicifolia L.

50. Syringa emodi Wall. ex Royle

51. Syringa komarowii C. K. Schneid.

52. Syringa reticulata (Blume) $\mathrm{H}$. Hara

53. Syringa reticulata subsp. amurensis (Rupr.) P. S. Green \& M. C. Chang (= Syringa amurensis Rupr.)

54. Syringa oblata Lindl.

55. Syringa villosa Vahl

56. Syringa villosa subsp. wolfii (C. K. Schneid.) Jin Y. Chen \& D. Y. Hong (= Syringa wolfii C. K. Schneid.)

57. Syringa tomentella subsp. sweginzowii (Koehne \& Lingelsh.) Jin Y. Chen \& D. Y. Hong (= Syringa sweginzowii Koehne \& Lingelsh.)

58. Syringa tomentella subsp. yunnanensis (Franch.) Jin Y. Chen \& D. Y. Hong (= Syringa yunnanensis Franch.)

59. Tilia amurensis Rupr.

60. Viburnum sargentii Koehne 
Таблица 2. Развитие сеянцев древесных растений восточно-азиатской флоры в условиях интродукции в Ботаническом саду Петргу

Table 2. The growing of seedlings of East Asian woody plants in the nursery of Botanic Garden of PetrSU

\begin{tabular}{|c|c|c|c|c|c|}
\hline № & Вид & $\begin{array}{l}\text { Количество } \\
\text { исследуемых } \\
\text { растений } \\
\end{array}$ & $\begin{array}{l}\text { Появление } \\
\text { всходов, год } \\
\text { после посева }\end{array}$ & $\begin{array}{l}\text { Ювенильное } \\
\text { состояние: } \\
\text { возраст, лет }\end{array}$ & $\begin{array}{l}\text { Имматурное } \\
\text { состояние: } \\
\text { возраст, лет }\end{array}$ \\
\hline & Pinophyta & & & & \\
\hline 1 & Abies holophylla Maxim. & 9 & 1 & 1 & $3-4$ \\
\hline 2 & $\begin{array}{l}\text { Abies nephrolepis (Trautv. ex Maxim.) } \\
\text { Maxim. }\end{array}$ & 2 & 1 & 1 & 2 \\
\hline 3 & Abies sachalinensis (F. Schmidt) Mast. & 11 & 1 & 1 & 2 \\
\hline 4 & $\begin{array}{l}\text { Abies sachalinensis var. mayriana } \\
\text { Miyabe \& Kudô (= Abies mayriana } \\
\text { (Miyabe \& Kudô) Miyabe \& Kudô) }\end{array}$ & 8 & 1 & 1 & 2 \\
\hline 5 & Abies veitchii Lindl. & 14 & 1 & 1 & нет данных \\
\hline 6 & $\begin{array}{l}\text { Juniperus chinensis var. sargentii A. } \\
\text { Henry (=Juniperus sargentii (A. Henry) } \\
\text { Takeda ex Nakai) }\end{array}$ & 2 & $2-3$ & 1 & 2 \\
\hline 7 & Larix gmelinii (Rupr.) Kuzen. & 5 & 1 & 1 & $1-2$ \\
\hline 8 & $\begin{array}{l}\text { Larix gmelinii var. olgensis (A. Henry) } \\
\text { Ostenf. \& Syrach (= Larix olgensis A. } \\
\text { Henry) }\end{array}$ & 6 & 1 & 1 & 2 \\
\hline 9 & Picea asperata Mast. & 15 & 1 & 1 & 2 \\
\hline 10 & Picea glehnii (F. Schmidt) Mast. & 6 & 1 & 1 & 2 \\
\hline 11 & Picea jezoensis (Siebold \& Zucc.) Carrière & 27 & 1 & 1 & $2-3$ \\
\hline 12 & Picea retroflexa Mast. & 93 & 1 & 1 & $2-3$ \\
\hline 13 & Pinus densiflora Siebold \& Zucc. & 61 & 1 & 1 & 3 \\
\hline \multirow[t]{2}{*}{14} & Pinus koraiensis Siebold \& Zucc. & 4 & 1 & 1 & 4 \\
\hline & Magnoliophyta & & & & \\
\hline 15 & Acer barbinerve Maxim. ex Miq. & 1 & 2 & 1 & нет данных \\
\hline 16 & Acer pseudosieboldianum (Pax) Kom. & 5 & 2 & 1 & $2-3$ \\
\hline 17 & Berberis koreana Palib. & 1 & 1 & 1 & 3 \\
\hline 18 & Berberis thunbergii DC. & 15 & 1 & 1 & 1 \\
\hline 19 & Betula dahurica Pall. & 4 & 1 & 1 & 2 \\
\hline 20 & Betula ermanii Cham. & 4 & & 1 & 2 \\
\hline 21 & $\begin{array}{l}\text { Betula nana subsp. exilis (Sukaczev) } \\
\text { Hultén }\end{array}$ & 3 & 2 & 1 & 2 \\
\hline 22 & Betula utilis D. Don & 1 & 1 & 1 & 1 \\
\hline 23 & Caragana boisii C. K. Schneid. & 3 & 1 & 1 & 3 \\
\hline 24 & Caragana microphylla Lam. & 4 & 1 & 1 & 2 \\
\hline 25 & Chaenomeles speciosa (Sweet) Nakai & 9 & 2 & 1 & 3 \\
\hline 26 & Corylus heterophylla Fisch. ex Trautv. & 4 & 1 & 1 & 2 \\
\hline 27 & Cotoneaster horizontalis Decne. & 5 & 2 & 1 & 1 \\
\hline 28 & Crataegus chlorosarca Maxim. & 18 & 1 и 2 & 1 & $2-3$ \\
\hline 29 & $\begin{array}{l}\text { Crataegus dahurica Koehne ex C. K. } \\
\text { Schneid. }\end{array}$ & 10 & 2 & 1 & $3-4$ \\
\hline 30 & Crataegus maximowiczii C. K. Schneid. & 3 & 2 & 1 & нет данных \\
\hline 31 & Crataegus pinnatifida Bunge & 5 & 2 & 1 & $2-3$ \\
\hline 32 & Euonymus alatus (Thunb.) Siebold & 24 & 2,3 & 1 & $2-3$ \\
\hline 33 & Euonymus hamiltonianus Wall. & 10 & 2 & 1 & 3- 4 \\
\hline 34 & Euonymus maackii Rupr. & 15 & 1 & 1 & $2-3$ \\
\hline 35 & Euonymus macropterus Rupr. & 14 & 1 & 1 & $2-3$ \\
\hline 36 & $\begin{array}{l}\text { Euonymus sachalinensis (F. Schmidt) } \\
\text { Maxim. }\end{array}$ & 1 & 1 & 1 & 2 \\
\hline 37 & Lespedeza bicolor Turcz. & 7 & 1 и 2 & 1 & 2 \\
\hline 38 & Lonicera chrysantha Turcz. ex Ledeb. & 1 & 1 & 1 & 2 \\
\hline 39 & Lonicera ferdinandii Franch. & 12 & 1 & 1 & 2 \\
\hline 40 & Lonicera gibbiflora Dipp. & 5 & 1 & 1 & 2 \\
\hline 41 & Maackia amurensis Rupr. & 30 & 1 и 2 & 1 & 3 \\
\hline 42 & Malus sieboldii (Regel) Rehder & 1 & 3 & 1 & 2 \\
\hline 43 & Menispermum dauricum DC. & 24 & 1 & 1 & 2 \\
\hline 44 & Phellodendron amurense Rupr. & 11 & 2 & 1 & 3- 4 \\
\hline 45 & $\begin{array}{l}\text { Philadelphus subcanus var. magdalenae } \\
\text { (Koehne) S. Y. Hu }\end{array}$ & 18 & 1 & 1 & 3 \\
\hline 46 & Prinsepia sinensis (Oliv.) Oliv. ex Bean & 15 & 1 & 1 & 2 \\
\hline 47 & Prinsepia uniflora Batalin & 2 & 1 & 1 & 2 \\
\hline 48 & Prunus sachalinensis (F. Schmidt) Koidz. & 1 & 2 & 1 & 2 \\
\hline 49 & Quercus mongolica subsp. crispula & 2 & 1 & 1 & 2 \\
\hline
\end{tabular}


(Blume) Menitsky

\begin{tabular}{llllll}
\hline 50 & Rhamnus erythroxylon Pall. & 8 & 1 & 1 & $2-3$ \\
\hline 51 & Rhodotypos scandens (Thunb.) Makino & 5 & 2 & 1 & 2 \\
\hline 52 & Rosa multiflora Thunb. & 4 & 1 и 2 & 1 & 2 \\
\hline 53 & $\begin{array}{l}\text { Sibiraea laevigata (L.) Maxim. (Sibiraea } \\
\text { altaiensis (Laxm.) C. K. Schneid.) }\end{array}$ & 14 & 1 и 2 & 1 & Heт данных \\
\hline 54 & $\begin{array}{l}\text { Sorbus aucuparia L. (=S. amurensis } \\
\text { Koehne) }\end{array}$ & 9 & 1 & 1 & 2 \\
\hline 55 & Sorbus koehneana C. K. Schneid. & 3 & 2 & 1 & 2 \\
\hline 56 & $\begin{array}{l}\text { Sorbus sambucifolia (Cham. \& Schltdl.) } \\
\text { M. Roem. }\end{array}$ & 6 & 2 & 1 & $2-3$ \\
\hline 57 & Sorbus tianschanica Rupr. & 3 & $1-4$ & 2 \\
\hline 58 & Tilia mongolica Maxim. & 1 & 3 & 1 & $2-3$ \\
\hline 59 & Weigela praecox (Lemoine) Bailey & 41 & 1 и 2 & 1 & 2 \\
\hline 60 & Weigela subsessilis (Nakai) L. H. Bailey & 4 & 1 & 1 & 2 \\
\hline
\end{tabular}

Таблица 3. Зимостойкость сеянцев древесных растений восточно-азиатской флоры в условиях интродукции в Ботаническом саду Петргу

Table 3. The winter hardiness of seedlings of East Asian woody plants in the nursery of Botanic Garden of PetrSU

\begin{tabular}{|c|c|c|c|}
\hline № & Вид & $\begin{array}{l}\text { Количество } \\
\text { исследуемых } \\
\text { растений }\end{array}$ & Зимостойкость, баллы* \\
\hline & Pinophyta & & \\
\hline 1 & Abies holophylla Maxim. & 9 & VIIa \\
\hline 2 & Abies nephrolepis (Trautv. ex Maxim.) Maxim. & 2 & $\mathrm{I}$ \\
\hline 3 & Abies sachalinensis (F. Schmidt) Mast. & 11 & VIIa \\
\hline 4 & $\begin{array}{l}\text { Abies sachalinensis var. mayriana Miyabe \& Kudô (= Abies } \\
\text { mayriana (Miyabe \& Kudô) Miyabe \& Kudô) }\end{array}$ & 8 & VIIa \\
\hline 5 & Abies veitchii Lindl. & 14 & $\mathrm{I}$ \\
\hline 6 & $\begin{array}{l}\text { Juniperus chinensis var. sargentii A. Henry (= Juniperus } \\
\text { sargentii (A. Henry) Takeda ex Nakai) }\end{array}$ & 2 & $\mathrm{I}$ \\
\hline 7 & Larix gmelinii (Rupr.) Kuzen. & 5 & VIIa \\
\hline 8 & $\begin{array}{l}\text { Larix gmelinii var. olgensis (A. Henry) Ostenf. \& Syrach (= Larix } \\
\text { olgensis A. Henry) }\end{array}$ & 6 & VIIa \\
\hline 9 & Picea asperata Mast. & 15 & VIIa \\
\hline 10 & Picea glehnii (F. Schmidt) Mast. & 6 & $\mathrm{I}$ \\
\hline 11 & Picea jezoensis (Siebold \& Zucc.) Carrière & 27 & VIla \\
\hline 12 & Picea retroflexa Mast. & 93 & $\mathrm{I}$ \\
\hline 13 & Pinus densiflora Siebold \& Zucc. & 61 & $\mathrm{I}$ \\
\hline \multirow[t]{2}{*}{14} & Pinus koraiensis Siebold \& Zucc. & 4 & $\mathrm{I}$ \\
\hline & Magnoliophyta & & \\
\hline 15 & Acer barbinerve Maxim. ex Miq. & 1 & $\mathrm{I}$ \\
\hline 16 & Acer pseudosieboldianum (Pax) Kom. & 5 & $\mathrm{I}$ \\
\hline 17 & Berberis koreana Palib. & 1 & $\mathrm{I}$ \\
\hline 18 & Berberis thunbergii DC. & 15 & $\mathrm{I}$ \\
\hline 19 & Betula dahurica Pall. & 4 & $\mathrm{I}$ \\
\hline 20 & Betula ermanii Cham. & 4 & VIIa \\
\hline 21 & Betula nana subsp. exilis (Sukaczev) Hultén & 3 & $\mathrm{I}$ \\
\hline 22 & Betula utilis D. Don & 1 & $\mathrm{I}$ \\
\hline 23 & Caragana boisii C. K. Schneid. & 3 & VIIa \\
\hline 24 & Caragana microphylla Lam. & 4 & $\mathrm{I}$ \\
\hline 25 & Chaenomeles speciosa (Sweet) Nakai & 9 & VIla \\
\hline 26 & Corylus heterophylla Fisch. ex Trautv. & 4 & $\mathrm{I}$ \\
\hline 27 & Cotoneaster horizontalis Decne. & 5 & VIIa \\
\hline 28 & Crataegus chlorosarca Maxim. & 18 & VIIIa \\
\hline 29 & Crataegus dahurica Koehne ex C. K. Schneid. & 10 & VIIa \\
\hline 30 & Crataegus maximowiczii C. K. Schneid. & 3 & $\mathrm{I}$ \\
\hline 31 & Crataegus pinnatifida Bunge & 5 & $\mathrm{~T}$ \\
\hline 32 & Euonymus alatus (Thunb.) Siebold & 24 & VII6 \\
\hline 33 & Euonymus hamiltonianus Wall. & 10 & VIla \\
\hline 34 & Euonymus maackii Rupr. & 15 & VIla \\
\hline 35 & Euonymus macropterus Rupr. & 14 & VIIa \\
\hline 36 & Euonymus sachalinensis (F. Schmidt) Maxim. & 1 & $\mathrm{I}$ \\
\hline 37 & Lespedeza bicolor Turcz. & 7 & III, VIIa \\
\hline 38 & Lonicera chrysantha Turcz. ex Ledeb. & 1 & $\mathrm{I}$ \\
\hline 39 & Lonicera ferdinandii Franch. & 12 & II, VIIa \\
\hline
\end{tabular}




\begin{tabular}{|c|c|c|c|}
\hline 40 & Lonicera gibbiflora Dipp. & 5 & II, III, VIIa \\
\hline 41 & Maackia amurensis Rupr. & 30 & VIIa \\
\hline 42 & Malus sieboldii (Regel) Rehder & 1 & $\mathrm{~T}$ \\
\hline 43 & Menispermum dauricum DC. & 24 & III \\
\hline 44 & Phellodendron amurense Rupr. & 11 & $\mathrm{I}$ \\
\hline 45 & Philadelphus subcanus var. magdalenae (Koehne) S. Y. Hu & 18 & II, VIIa \\
\hline 46 & Prinsepia sinensis (Oliv.) Oliv. ex Bean & 15 & II, III \\
\hline 47 & Prinsepia uniflora Batalin & 2 & VIIa \\
\hline 48 & Prunus sachalinensis (F.Schmidt) Koidz. & 1 & $\mathrm{I}$ \\
\hline 49 & Quercus mongolica subsp. crispula (Blume) Menitsky & 2 & VIIa \\
\hline 50 & Rhamnus erythroxylon Pall. & 8 & $\mathrm{I}$ \\
\hline 51 & Rhodotypos scandens (Thunb.) Makino & 5 & $\mathrm{III}, \mathrm{VIIa}$ \\
\hline 52 & Rosa multiflora Thunb. & 4 & II, VIIa \\
\hline 53 & $\begin{array}{l}\text { Sibiraea laevigata (L.) Maxim. (Sibiraea altaiensis (Laxm.) C. K. } \\
\text { Schneid.) }\end{array}$ & 14 & $\mathrm{~T}$ \\
\hline 54 & Sorbus aucuparia L. (= S. amurensis Koehne) & 9 & $\mathrm{I}$ \\
\hline 55 & Sorbus koehneana C. K. Schneid. & 3 & l \\
\hline 56 & Sorbus sambucifolia (Cham. \& Schltdl.) M.Roem. & 6 & VIIa \\
\hline 57 & Sorbus tianschanica Rupr. & 3 & I \\
\hline 58 & Tilia mongolica Maxim. & 1 & $\mathrm{~T}$ \\
\hline 59 & Weigela praecox (Lemoine) Bailey & 41 & VII6 \\
\hline 60 & Weigela subsessilis (Nakai) L. H. Bailey & 4 & VII6 \\
\hline
\end{tabular}

* I - повреждений нет (растение не обмерзает); II - обмерзает не более половины длины однолетних побегов; III - обмерзают однолетние побеги полностью; IV - обмерзают двулетние и более старые части растений; V - обмерзает крона до уровня снегового покрова; VI - обмерзает вся надземная часть; VII - растение вымерзает полностью (а - единичный выпад некоторых растений, 6 - полностью вымерзает около половины растений образца).

* I - no damage (the plant is not frosting); II - frosted no more than half the length of the one-year shoots; III - frosted over annual shoots in full; IV - frosted biennial and older parts of plants; V - frosted crown to the level of snow cover; VI - frosted whole aboveground part; VII - a plant freezes completely (a - mortality of single seedlings, b - mortality of $50 \%$ investigated seedlings).

\section{Выводы и заключение}

В составе коллекций Ботанического сада насчитывается 73 вида древесных растений восточноазиатской флоры, принадлежащих 43 родам, 20 семейству, 19 порядкам, 3 классам, 3 отделам. Ареал 72 \% видов располагается полностью или частично в России, 28 \% видов имеют ареал за пределами страны. Два вида занесены в Красную книгу России, еще 8 видов - в региональные Красные книги Дальнего Востока России. Три вида отмечены Международным союзом охраны природы как исчезающие, находящиеся в состоянии, близком к угрожающему и уязвимые.

Полученные положительные результаты многолетней интродукции позволяют более широко рекомендовать 56 видов (60 таксонов с учетов подвидов) древесных растений восточноазиатского происхождения для использования в зеленых насаждениях урбанизированных территорий южной Карелии.

В 2013-15 годах коллекция Ботанического сада пополнилась образцами 58 видов (60 таксонов с учетом подвидов) древесных растений восточноазиатского происхождения, принадлежащих 32 родам, 15 семействам, 10 порядкам, 2 отделам. Среди них 5 видов включено в Красную книгу России, 3 вида дополнительно в региональные книги Дальнего Востока, два - в категориях уязвимых и под угрозой исчезновения по данным Международного союза охраны природы.

Оценка зимостойкости и особенностей развития сеянцев позволила сделать первые выводы высокой жизнеспособности образцов 20 видов восточноазиатского происхождения на ранних этапах развития в условиях Южной Карелии.

Анатомические исследования могут значительно дополнить информацию о развитии и устойчивости интродуцируемых растений. Установлено, что среди исследованных сеянцев видов хвойных у Abies holophylla, Picea jezoensis, Picea retroflexa, Pinus densiflora нарушения в развитии тканевых структур не наблюдались. Происходит нормальное формирование тканей в условиях 
интродукции.

\section{Благодарности}

Благодарим заведующую кафедрой ботаники Эколого-биологического факультета д.б.н. Е. Ф. Марковскую за помощь в организации исследований. Работа выполнена при поддержке Программы стратегического развития Петрозаводского государственного университета (ПСР 2016).

\section{Литература}

Бессчетнов В. П., Бессчетнова Н. Н. Образование и лигнификация ксилемы плюсовых деревьев сосны обыкновенной // Известия вузов. Лесной журнал. [Formation and Lignification of Xylem of Scotch Pine Elite Trees // Bulletin of higher educational institutions. Lesnoy zhurnal] 2013. № 2. C. 45-52.

Воробьев Д. П. Дикорастущие деревья и кустарники Дальнего Востока. [Wild trees and shrubs of Far East] Л: Наука, Ленинградское Отделение, 1968. 277 с.

Воробьев Д. П. Определитель деревьев и кустарников Приморья и Приуралья. [Guide for identification of trees and shrubs of Primorye and Priuralye] Благовещенск, 1955. 267 с.

Диагнозы и ключи возрастных состояний лесных растений. Деревья и кустарники: методические разработки для студентов биологических специальностей. [Diagnosis and keys for ontogenetic stages of forest plants. Trees and shrubs] / Ред. Смирнова О. В., Заугольнова Л. Б. и др. Ч. 1 М.: Изд-во "Прометей" мГПУ им. В. И. Ленина, 1989. 102 с.

Еглачева А. В., Лопинова Е. В., Принцева И. В. Хвойные растения в декоративном арборетуме Ботанического сада Петрозаводского государственного университета. [Conifers in decorative arboretum of Botanic Garden of Petrozavodsk State University // Hortus Bot.] // Hortus bot. 2014. T. 9. URL: http://hb.karelia.ru/journal/article.php?id=2403. DOI: 10.15393/j4.art.2014.2403.

Кауров И. А. Итоги интродукции дальневосточных древесных и кустарниковых пород в районе Ленинграда // Бюллетень Главного ботанического сада АН СССР. [The results of ex-situ growing of Far East trees and shrubs in Leningrad region // Byulleten Glavnogo botanicheskogo sada AN SSSR ] 1961. Вып. 41. C. $3-11$.

Красная книга Амурской области: Редкие и находящиеся под угрозой исчезновения виды животных, растений и грибов. [Red Data Book of Amurskaja oblast: Rare and endangered plant animal and fungi species] / Ред. Кожемяко О. Н. и др. Благовещенск: Издательство БГПУ, 2009. 446 с.

Красная книга Приморского края: растения. Редкие и находящиеся под угрозой исчезновения виды растений и грибов. [Red Data Book of Primorskyi krai: Plants. Rare and endangered plant, animal and fungi species] Владивосток: АВK «Апельсин», 2008. 688 с.

Красная книга Российской Федерации (растения и грибы) [Red Data Book of the Russian Federation (Plants and Fungi] / Гл. ред. колл.: Ю. П. Трутнев и др.; Сост. Р. В. Камелин и др. М.: Товарищество научных изданий KMK, 2008. 885 с.

Красная книга Сахалинской области. Растения [Red Data Book of Sahalinskaya oblast. Plants] / Отв. ред. проф. д.б.н. В. М. Еремин. Южно-Сахалинск: Сахалинское книжное издательство, 2005. 348 с.

Красная книга Хабаровского края: Редкие и находящиеся под угрозой исчезновения виды растений и животных: официальное издание [Red Book of the Khabarovsky krai: Rare and endangered plant and animal species] / Министерство природных ресурсов Хабаровского края, Институт водных и экологических проблем ДВО РАН. Хабаровск: Издательский дом «Приамурские ведомости», 2008. 632 с.

Куликов В. С., Куликова В. В. Докембрийская геология территории Ботанического сада // Hortus Bot. [Precambrian geology of the Botanical garden territory // Hortus Bot.] 2001. 1. Р. 19-24. 
Лантратова А. С., Еглачева А. В., Марковская Е. Ф. Древесные растения, интродуцированные в Карелии (история, современное состояние). [Woody plants in culture in Karelia (history, modern state)] Петрозаводск: Изд-во Петргу, 2007. 196 с.

Лантратова А. С., Ициксон Е. Е., Марковская Е. Ф., Куспак Н. В. Сады и парки в истории Петрозаводска. [Gardens and parks through the history of Petrozavodsk] Петрозаводск: ПетроПресс, 2003. 160 с.

Лапин П. И., Сиднева С. В. Оценка перспективности интродуцированных древесных растений по данным визуального наблюдения // Опыт интродукции древесных растений. [Estimation of prospectivity of introducted woody plants by visual observation // The experience of woody plants introduction] М.: Наука, 1973. C. 7-67.

Лучник 3. И. Интродукция деревьев и кустарников в Алтайском крае. [Introduction of trees and shrubs in Altayskyi krai] М.: Колос, 1970. 655 с.

Нестерович Н. Д. Акклиматизация древесных растений в зеленом строительстве и лесном хозяйстве Белорусской ССР. [Akklimatization of woody plants in urban forestry of Byelorussia] Минск: Изд-во АН БССР, 1950. 43 с.

Николаева М. Г., Разумова В. Н. Справочник по проращиванию покоящихся семян. [Handbook of resting seeds germination] Л.: Наука, 1985. 348 с.

Петухова И. П. Эколого-физиологические предпосылки интродукции дальневосточных древесных растений // Ритм роста и развития интродуцентов. [Ecologo-physiological precondition for the introduction of Far East woody plants // Rhythm of growth of introductive plants] M: Наука, 1973. С. 101-104.

Тахтаджян А. Л. Флористические деления суши // Жизнь растений. [Floristic division of land // The Life of Plants]. Т. 1. М.: Просвещение, 1974. С. 117-153.

Тахтаджян А. Л. Флористические области Земли. [Floristic Regions of the World] Л.: Наука, 1978. 248 с.

Magarey R. D., Borchert D. M., Schlegel J. W. Global plant hardiness zones for phytosanitary risk analysis // Scientia Agricola 01/2008. 65. P. 54-59.

The IUCN (International Union for Conservation of Nature and Natural Resources) Red List of Threatened Species 2016 - 2. http://www.iucnredlist.org/search?page=1 (дата обращения 7.12.2016).

The Plant List, 2013. Version 1.1. Published on the Internet. http://www.theplantlist.org/ (accessed 1st January). http://www.theplantlist.org/ (дата обращения 20.10.2016).

Waddington C. H. Canalization of development and the inheritance of acquired characters // Nature. 1942. Vol. 150. P. 563-565.

\title{
Species of East Asian flora in the Botanic garden of Petrozavodsk State University
}

\author{
PLATONOVA \\ Elena \\ Petrozavodsk State University, meles@sampo.ru
}

\section{LANTRATOVA} Antonina

ZADORKINA Ekaterina

Petrozavodsk State University, mih_val@mail.ru

Petrozavodsk State University, garden@psu.karelia.ru

\section{Keywords:}

Annotation: 
science, ex situ, Botanic garden, East Asia, introduction, woody plants, ontogenesis, stem anatomy
Collection of East Asian woody plants of the Botanic Garden of Petrozavodsk State University includes 73 species, which include to 43 genus, 20 families, 19 orders, 3 classes, 3 divisions. Distribution area of most species $(72 \%)$ located wholly or partly in Russia, the rest of them have natural habitats in the other countries. 13 species are rare and endangered and protected by local, Russian Red Data books and IUCN. Some other diversity parameters of investigated species (life form, age and ontogenetic stage) also are presented. According to positive results of long-term growing and investigation in the Botanical Garden of PetrSU 56 species can be allowed recommending for more widely use in the green areas of South Karelia. In 2013-2015 seeds of 58 new species of East Asian woody plants were received from 39 Botanic gardens of Russia and some European countries. For seedlings of this species the characteristic of the early ontogenetic stages are presented. Anatomy of Abies holophylla, Picea jezoensis, Picea retroflexa, Pinus densiflora seedlings is analyzed. According to preliminary data 20 species of East Asian origin in the early stages of development are the best viable in South Karelia.

Цитирование: Платонова Е. А., Лантратова А. С., Задоркина Е. А. Восточноазиатские элементы флоры в Ботаническом саду Петрозаводского государственного университета // Hortus bot. 2016. 11, URL: http://hb.karelia.ru/journal/article.php?id=2964. DOI: 10.15393/j4.art.2016.2964

Cited as: Platonova E., Lantratova A. S., Zadorkina E. A. "Species of East Asian flora in the Botanic garden of Petrozavodsk State University" // Hortus bot. 11, (2016): DOI: 10.15393/j4.art.2016.2964 